\title{
ESTABLISHING REGIONAL ANTI-FRAUD OFFICE TO TACKLE FINANCIAL CRIME IN ASEAN
}

\author{
Reza Haidar Kamal \\ University of Diponegoro \\ rezahaidarkamal@gmail.com
}

\section{ARTICLE INFORMATION}

Article history:

Received July 31, 2016

Revised Dec 10, 2016

Accepted May 15, 2017

JEL Classifications

F52; K33; K42

\section{Key Words:}

Fraud;

Corruption;

ASEAN;

European Union;

OLAF

DOI:

10.21532/apfj.001.17.02.01.06

\begin{abstract}
Corruption is still becoming hot issue around the world. Each country has its own way to combat corruption starting from the scope of national, regional to international cooperation to fight against this issue. Indonesia also has several strategies to eradicate corruption which are getting better from time to time. According to Transparency International (TI), as a member of regional organization, ASEAN, Indonesia is still ranked fourth,in Corruption Perception Index (CPI), out of tenmember countries. But the rank-range of ASEAN member countries is too far from one country to another, unlike European Union. Three member countries of European Union stand are on the top three of 168 countries. Besides having anti-corruption institution in each member country, European Union also has anti-fraud office, called OLAF, to tackle financial crime at regional level. Therefore, it is necessary for ASEAN to establish an institution that aims to combat corruption at regional level of ASEAN, just like the European Union's OLAF, which has a mandate to detect, investigate and stop fraud related to EU's funds.
\end{abstract}

\section{DISCUSSION}

Corruption is a white-collar crime that attracts international attention. The issue of corruption occurring in almost all countries has made the international community aware of the importance of anti-corruption instrument that could help the world fight against corruption. (UNODC, Compendium of International Legal Instruments on Corruption, 2005)

Corruption itself is defined as a dangerous plague that has a wide range of corrosive effects on societies. Corruption undermines democracy and the rule of law, violates the human rights, distorts markets, erodes the quality of life and allows organized crime, terrorism and other threats to 
human security to flourish. (UNODC, United Nations Convention against Corruption, 2004).

Asian Development Bank defines corruption as the abuse of public or private office for personal gain. This means any behavior in which people in the public or private sector improperly and unlawfully engage in activities that aim to enrich themselves or those close to them, or induce others to do so by misusing their positions. (Asian Development Bank, 1998).

Corruption can occur anywhere, in all large and small countries, developed and developing countries. However, corruption has the most damaging effectin developing countries. Corruption hurts the poor by diverting funds intended for development. For the government,corruption also undermines the government's ability to provide basic services, causes the food needs to be unbalanced and reduces the allocation of funds for foreign aid and investment. Corruption is a key element in low economic performance and corruption is a major obstacle in poverty alleviation and development in developing countries. (UNODC, United Nations Convention Against Corruption, 2004).

Transparency International (TI) Institution has released the data on the Corruption Perception Index (CPI) which indicates the level of corruption of 168 countries. In the latest data in 2015, Indonesia was ranked 88 of 168 countries, whereas, in previous year, 2014, Indonesia was ranked 107th.

Table 1

Corruption Perception Index 2012-2015

\begin{tabular}{|c|c|c|c|c|c|}
\hline Rank & Country & 2012 & 2013 & 2014 & 2015 \\
\hline 88 & Indonesia & 32 & 32 & 34 & 36 \\
\hline
\end{tabular}

Source: transparency.com)

Based on the above table, it can be seen that the level of corruption in Indonesia from 2012 to 2015 tends to decline, because the higher the score of the Corruption Perception Index (CPI), the cleaner the country from corruption.

According to Ilham Saenong, a Program Director of Indonesian Transparency International, the increase in Indonesia's Corruption Perception Index is affected by the increased public accountability and the prevention of corruption which is considered effective. This progress cannot be separated from of efforts of the Corruption Eradication
Commission (KPK) in Indonesia.

Rank 168 is an image of the durability and the efforts of the government and community of each country in suppressing corruption. The average score of the ASEAN region in 2015 is 38. Thisindicates that Indonesia, as a member of ASEAN, is still below average. Indonesia is still below Singapore, Malaysia and Thailand.

Corruption Perception Index (CPI) is a composite index that refers to the perception in which the data owned by the Corruption Perception Index (CPI) are obtained from several sources, among others, are the World 
Economic Forum in 2015 and the Bertelsmann Foundation Index. Corruption Perception Index (CPI) describes the perception of corruption over the abuse of authority for personal interests that include the public sector, public administration and politics.

However, according to the Program Director of Indonesian Transparency International, the Corruption Perception Index (CPI) is not an instrument that can measure corruption significantly since the assessment is limited to perception only, and absolutely, corruption is difficult to measure because it is veiled. (Transparency International Indonesia, 2016).

Tabel 2

Corruption Perception Indexof ASEAN Member Countries 2012-2015

\begin{tabular}{|c|c|c|c|c|c|c|}
\hline No & Ranking & Country & 2012 & 2013 & 2014 & 2015 \\
\hline 1 & 8 & Singapore & 87 & 86 & 84 & 85 \\
\hline 2 & 54 & Malaysia & 49 & 50 & 52 & 50 \\
\hline 3 & 76 & Thailand & 37 & 35 & 38 & 38 \\
\hline 4 & 88 & Indonesia & 32 & 32 & 34 & 36 \\
\hline 5 & 95 & Philippines & 34 & 36 & 38 & 35 \\
\hline 6 & 112 & Vietnam & 31 & 31 & 31 & 31 \\
\hline 7 & 139 & Laos & 21 & 26 & 25 & 25 \\
\hline 8 & 147 & Myanmar & 15 & 21 & 21 & 22 \\
\hline 9 & 150 & Cambodia & 22 & 20 & 21 & 21 \\
\hline
\end{tabular}

Source: transparency.com

The data above is the ranking of corruption of ASEAN member countries, except Brunei Darussalam that is not included in the data of Transparency International. There is only one country that enters the top ten countries, ie Singapore, while other ASEAN member countries enter the top 50 down. This reflects the imbalances within ASEAN itself.
The researchers would like to compare the ranking between ASEAN member countries and the EU member countries, where the European Union is a regional organization that is also studied by ASEAN as a regional organization pilot. Table of the ranking of EU countries is as follows: 
Table 3

Corruption Perception Indexof EU Member Countries 2012-2015

\begin{tabular}{|c|c|c|c|c|c|c|}
\hline No & Ranking & Country & 2012 & 2013 & 2014 & 2015 \\
\hline 1 & 1 & Denmark & 90 & 91 & 92 & 91 \\
\hline 2 & 2 & Finland & 90 & 89 & 89 & 90 \\
\hline 3 & 3 & Sweden & 88 & 89 & 87 & 89 \\
\hline 4 & 10 & Germany & 79 & 78 & 79 & 81 \\
\hline 5 & 15 & Belgium & 75 & 75 & 76 & 77 \\
\hline 6 & 16 & Austria & 69 & 69 & 72 & 76 \\
\hline 7 & 18 & Ireland & 69 & 72 & 74 & 75 \\
\hline 8 & 24 & Estonia & 64 & 68 & 69 & 70 \\
\hline 9 & 25 & France & 71 & 71 & 69 & 70 \\
\hline 10 & 32 & Cyprus & 66 & 63 & 63 & 61 \\
\hline 11 & 34 & Lithuania & 54 & 57 & 58 & 61 \\
\hline 12 & 35 & Slovenia & 61 & 57 & 58 & 60 \\
\hline 13 & 36 & Spain & 65 & 59 & 60 & 58 \\
\hline 14 & 37 & Czech Republic & 49 & 48 & 51 & 56 \\
\hline 15 & 40 & Latvia & 49 & 53 & 55 & 55 \\
\hline 16 & 51 & Croatia & 46 & 48 & 48 & 51 \\
\hline 17 & 52 & Hungary & 55 & 54 & 54 & 51 \\
\hline 18 & 53 & Slovakia & 46 & 47 & 50 & 51 \\
\hline 19 & 58 & Greece & 36 & 40 & 43 & 46 \\
\hline 20 & 61 & Italy & 42 & 43 & 43 & 44 \\
\hline 21 & 69 & Bulgaria & 41 & 41 & 43 & 41 \\
\hline
\end{tabular}

Source: transparency.com

It can be seen from the table of Corruption Perception Index of the EU member countries, that there are four countries in the top ten and even the big three, and all are EU member countries, while the lowest rank is 69 which is obtained by Bulgaria. The ranking of the EU member countries is said to be quite competitive among the member countries, the difference is not too far away.

Compared with ASEAN, the EU can be concluded better in coping with corruption. It is proven through the evenly result among the member countries, while in ASEAN, there are ranking inequality among the member countries. So it looks less compact, although they are in the same organization, ASEAN.

Based on these facts, the researchers consider the importance of ASEAN member countries to learn about the system applied by the European Union member countries on how they overcome the corruption together among member countries.

This could happen in ASEAN because of the absence of an agency that oversees fraud / corruption at ASEAN level. Meanwhile, EU 
already has an agency that functions specifically to address the fraud, including corruption, that is, OLAF (Office Européen de Lutteantifraude) or called The European Anti-Fraud Office.

OLAF is part of the EU Commission. This independent institution serves to tackle fraud that may affect the EU budget, including corruption or other awkward activities, including errors in the institutions of the European Union, accountably, transparently and cost-effectively. (OLAF, 2016).

OLAF has a hybrid or mixed status. On the one hand, OLAF is the Directorate General of the European Commission. On the other hand, OLAF is an independent agency in conducting investigation. This hybrid status of OLAF indicates that OLAF has investigative autonomy but reports to the commission as other tasks that do not affect the independence of OLAF investigation function. Being part of the EU Commission, OLAF is benefited not only from administrative and logistical support, but also from the anti-fraud law available to the commission department. (European Court of Auditors, 2005)

Figure 1

Diagram of OLAF Activities (2008-2015)

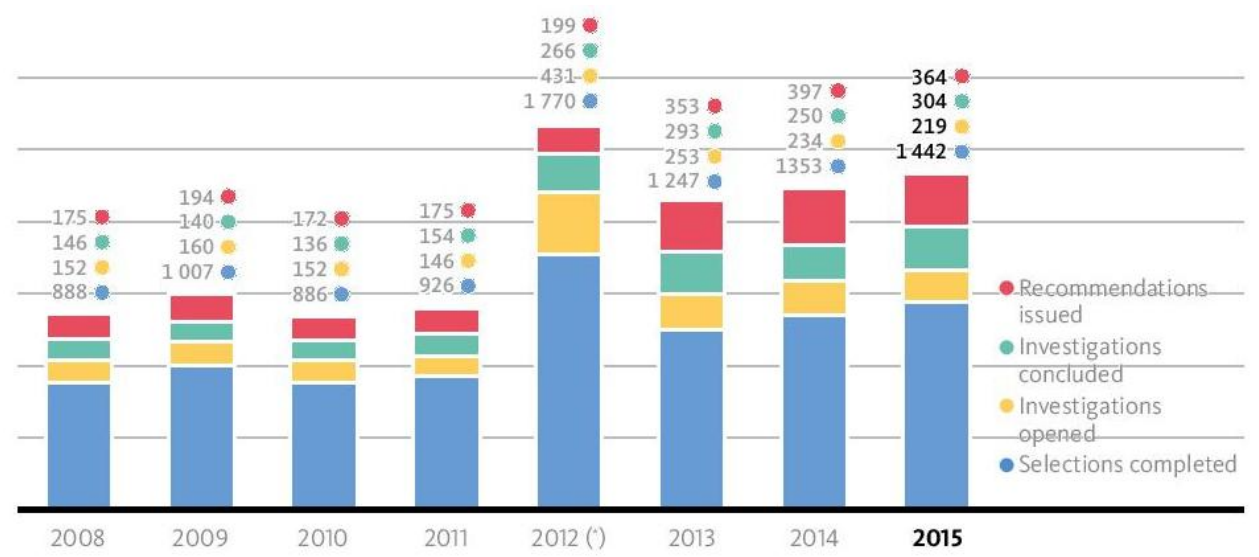

Source: The OLAF Annual Report 2015

The diagram shows the excellent performance of OLAF. There is a significant increase from 2012, because in 2012 OLAF performed re-organization within its institution to improve performance in the fight against frauds and proved successful until 2015. (OLAF, 2016)

There are four working steps conducted by OLAF:
1. Assessing and analyzing the incoming information to determine whether there are sufficient grounds to open an investigation into the case;

2. Performing an administrative investigation by building cooperation with the authorities of criminal or administrative investigative authority, the European Union and international bodies; 
3. Supporting the investigation of national authorities, providing recommendations on what action to be taken by the EU or national authorities;

4. Monitoring the action taken by the national authorities, assessing the effect of OLAF in the fight against fraud and supporting OLAF provides to the national authorities concerned. (OLAF, 2016)

As part of the European Commission, OLAF builds cooperation with the institutions, bodies and agencies of the European Union such as administrative agencies, the police, and the authorities in the member countries, to help each other to combat fraud, such as sharing information needed. (OLAF, 2016)

OLAF is also in cooperation with Eurojust (The European Union's Judicial Co-operation Body) and Europol (European Police Office) to achieve the same vision of realizing the European Union that is free from fraud, including corruption. This cooperation would benefit both sides because the parties can freely share information needed.

One of the cases handled by OLAF in 2014 was that OLAF issued recommendation of 1 million euro for the financial recovery of EU's major projects, namely transport projects, one of the big projects of the European Union in the field of transport which was aimed to facilitate the goods delivery via land transportation toward environmentally friendly form of transportation that does not damage the roads and environment. From this project, a private freight company received millions of euro. The results of the audit and further investigation by the commission, it was found irregularities in the violation of the rules of the program, where the company was proven to falsify the original data of the weight of the cargo which exceeded the prescribed limit. Then the commission reported the matter to OLAF. And then OLAF conducted field surveys and asked for the electronic records associated with this project and analyzed them. Finally, it was found violation which was committed by manipulating the report. The company dishonestly and systematically reported the most profitable number / digit derived from heavy load and transportation document. As a result, the average load including claims of costs became excessive.

Finally, OLAF issued a recommendation for a refund of 1 million euro, as the amount of losses and the cost of fines of European Union. This issue also attracted the attention of Italian Judicial Authorities. (OLAF, The OLAF Report 2014, 2015)

The example above is just one of many successes of OLAF in combating fraud. OLAF, as an anti-fraud agency of regional level in the European Union, is proven effective in dealing with financial crime at the regional level. The investigation is certainly not based on personal interests or the interest of the country because the members of this independent body are from the various countries. The aim is together to combat financial crime at EU level for achieving good governance.

The presence of anti-fraud office at the regional level of EU is a good sample for 
ASEAN. European Union builds regional cooperation to combat corruption even though the EU member countries themselves already have anti-corruption agencies in each country, but the presence of OLAF will make it easier for member countries to fight against corruption.

ASEAN, as a regional organization, also plans major projects involving member countries commonly called master plan. One of the examples of ASEAN master plan is the ASEAN Connectivity. ASEAN Connectivity is an important part in building the ASEAN Community. To achieve ASEAN Community, connectivity in in the fields of infrastructure, institutions and community interaction needs to be strengthened, and contributes toward a more competitive and flexible region, in which people, goods, services and capital are approximated among the member countries. ASEAN Connectivity is a program aimed at improving the lives of the ASEAN community by way of giving more opportunities to the ASEAN community and improving welfare through increased economic and social development. (ASEAN, 2011)

Basically corruption can occur in a variety of fields, as many people are getting smarter in finding loopholes to commit corruption. There is a possibility that corruption also occur in major projects planned by the ASEAN, such as cases in the European Union, where there are a lot of fraud and financial crimes occurred there. In the European Union there is OLAF that handles the cases, while in ASEAN, there has been no similar body like OLAF that handles the case of fraud at regional level.
Some ASEAN's member countries, including Indonesia, will be greatly helped in the fight against fraud with the presence of an agency like OLAFthat does not discriminate in conducting investigation and issuing recommendation. In addition, after the agency issues its recommendation, the recommendation will be returned to the parties concerned to follow-up. If a country does not implement the recommendation by sanctioning the perpetrators, the country will of course feel embarrassed for not enforcing anti-corruption in its own country. Furthermore, the cases of corruption / fraud will be known to all ASEAN member countries. So, with the existence of agency that controls fraud, including corruption at the regional level, some countries would help to combat corruption.

\section{CONCLUSION}

Realizing good governance requires good cooperation among countries, institutions, and communities to achieve a common vision towards the good governance.

Financial crime methods, including corruption, are increasingly diverse. There are several techniques that have not been predicted before, because the perpetrators are vying to commit crimes covertly so as not to be discovered and given legal sanction. Thus, the anti-corruption agencies also need to understand the latest methods used by the corruptors. To keep informed, anti-corruption agencies should collaborate with other agencies concerned to exchange ideas and share the data. 
ASEAN requires an agency that is responsible for fighting against fraud, like OLAF in the European Union. ASEAN has major projects that will be implemented with the cooperation among member countries. Fraud can possibly occur in the organization itself. So, anti-fraud or anti-corruption agency is required in ASEAN regional level.

\section{REFERENCES}

ASEAN. (2011). Master Plan on ASEAN Connectivity. Jakarta:ASEAN Secretariat.

Asian Development Bank. (1998). Anticorruption. Asian Development Bank.

European Court of Auditors. (2005). Special Report European Court of Auditors. Luxembourg: Publications Office of the European Union.

OLAF. (2015). The OLAF Report 2014. Luxembourg: Publications Office of the European Union.

OLAF. (2016). The OLAF Report 2015. Luxembourg: Publications Office of the European Union.

Transparency International Indonesia. (2016, January 26). Corruption Perceptions Index 2015. Retrieved July 2016, 28, from Transparency International Indonesia: http://www.ti.or.id/index. php/publication/2016/01/27/corruptionperceptions-index-2015

UNODC. (2004). United Nations Convention Against Corruption. New York: United Nations.
UNODC. (2005). Compendium of International Legal Instruments on Corruption. New York: United Nations. 